Letters to the Editor

\section{Prevalence of HIV-1, HBV, and HCV Among Patients Admitted to the Emergency Department of the Hospital de Base of the Federal District, Brazil}

\section{To the Editor:}

Transmission of bloodborne pathogens such as human immunodeficiency virus (HIV), hepatitis B virus (HBV), and hepatitis $\mathrm{C}$ virus (HCV) to healthcare workers at emergency departments is a matter of great concern. ${ }^{1,2}$ The aim of this study was to determine the prevalence of seropositivity to HIV-1, $\mathrm{HBV}$, and $\mathrm{HCV}$ among patients admitted in the Clinical Emergency Unit and the Trauma Unit of a tertiary hospital and reference trauma center in the Federal District of Brazil from November to December 1995. During this period, blood samples drawn for routine examinations from patients over 11 years of age admitted to those units were tested anonymously for HIV-1, HBV, and $\mathrm{HCV}$ serologies. Eight hundred twenty-six blood samples were collected: 549 from patients admitted to the Clinical Emergency Unit and 277 from patients admitted to the Trauma Unit. The prevalence ratio of bloodborne viruses in this population was compared with that obtained at the Central Blood Bank of Brasilia during the same period in 1995. Each serum sample was tested for the presence of antibodies to HIV-1, HBV, and HCV in the Health Institute of the Federal District according to standard techniques.

Prevalence rates for HIV-1, HBV, and $\mathrm{HCV}$ (based on positive and indeterminate results) in the Emergency Department were $5.4 \%, 4.1 \%$, and $2.4 \%$, respectively. When comparing the prevalence rates in patients admitted to the Emergency Department to those of blood donors, the prevalence ratio for HIV-1 was 14.20 (95\% confidence interval $\left.\left[\mathrm{CI}_{95}\right], 8.50-23.71\right)$, for
$\mathrm{HBV}$ was $15.07\left(\mathrm{CI}_{95}, 8.25-27.55\right)$, and for $\mathrm{HCV}$ was $3.79\left(\mathrm{CI}_{95}, 2.20-6.53\right)$. No significant differences were found when comparing the prevalence ratio of HIV-1, HBV, and HCV in the Clinical Emergency Unit and the Trauma Unit (2.02 [ $\left.\mathrm{CI}_{95}, 0.99-4.13\right]$, $1.96\left[\mathrm{CI}_{95}, 0.86-4.44\right]$, and $2.86\left[\mathrm{CI}_{95}\right.$, 0.85-9.69], respectively). However, there was a trend toward higher prevalence ratios for all pathogens in patients of the Clinical Emergency Unit compared to those of the Trauma Unit.

In our study, prevalence ratios of HIV-1, HBV, and HCV were higher among hospital patients than blood donors of the Central Blood Bank of Brasilia. Blood donors have been used by different authors to estimate the prevalence of HIV, HBV, and HCV infections in the general population. ${ }^{3}$ Among the 826 patients included in the present study, 6 were found to be positive for both HIV-1 and HCV, and 1 patient was positive for HIV-1 and HBV.

The possibility of coinfection reinforces the need for testing for all of these pathogens after an occupational exposure. The risk of acquiring an HBV infection from a percutaneous exposure to blood of a carrier of the virus varies from $2 \%$ to $40 \%$, depending on e-antigen status. ${ }^{4}$ In the same situation, the risk of contracting $\mathrm{HCV}$ varies from $1 \%$ to $9 \%$, and for HIV the risk is $0.4 \%{ }^{5}$

In summary, the prevalence of seropositivity for HIV-1, HBV, and $\mathrm{HCV}$ in patients of our Emergency Department is nearly 15-fold higher than in blood donors and is nearly 2 times higher than that of patients from the Trauma Unit (although no significant differences were found between these two groups of patients). These findings reinforce the importance of Universal or Standard Precautions for all health professionals, particularly those who work in emergency units.

\section{REFERENCES}

1. Kiyosawa $K$, Sodeyama $T$, Tanaka $E$, Nakano Y, Furuta S, Nishioka K, et al. Hepatitis $C$ in hospital employees with needlestick injuries. Ann Intern Med 1991;115:367-369.
2. Kunches LM, Craven DE, Werner BG, Jacobs LM. Hepatitis B exposure in emergency medical personnel. Prevalence of serologic markers and need for immunization. Am J Med 1983;75:269-272.

3. Uip DE, Amato VS, Amato Neto V, do Santos TJ, Mussi NS, Hamerschlak N. Serological evaluation for human immunodeficiency virus (HIV) and for hepatitis B (HBV) among candidates who have passed the admission test at a hospital institution in São Paulo [in Portuguese]. Rev Assoc Med Bras 1995;41:141-143.

4. Werner BG, Grady GF. Accidental hepatitis B-surface-antigen-positive inoculations: use of e antigen to estimate infectivity. $A n n$ Intern Med 1982;97:367-369.

5. Stricof RL, Morse DL. HTLV-III/LAV seroconversion following a deep intramuscular needlestick injury. $N$ Engl $J$ Med 1986; $314: 1115$.

Julival Ribeiro, MD

Ricardo Boaventura, MD

Rilson F. Moitinho, MD

Neila F. Moitinho, MD

Kleber N. Campos, MD

Hospital de Base of the Federal District Ruiter R. Silva, MSc

Geni N.N.L. Câmara, MSc Health Institute of the Federal District Brasilía, Brazil

\section{Bacterial Contamination of Hospital Physicians' Stethoscopes}

To the Editor:

Stethoscopes must be regarded as vectors of bacteria and other microorganisms, and therefore they may play an important role in the spread of nosocomial infections. Preventive measures in hospital infection control must include regular disinfection of devices and instruments. The effectiveness of disinfection often proves to be limited, since structural characteristics are not considered. Because of that, we recommend that stethoscopes' membranes not be wiped but instead sprayed with a disinfectant.

Many measures to prevent the spread of nosocomial infections, eg, 